\title{
Penerapan Model Discovery Learning Berbantuan Media Powerpoint Meningkatkan Hasil Belajar IPS Siswa SD
}

\author{
Ni Wyn Nonik Asriningsih'1*, I Wyn Sujana ${ }^{2}$, I Gst Ayu Putu Sri Darmawati ${ }^{3}$ \\ 1,2 Universitas Pendidikan Ganesha, Singaraja, Indonesia \\ ${ }^{3}$ Sekolah Dasar Negeri 1 Astina, Singaraja, Indonesia
}

\section{ART I CLE I N F O}

Article history:

Received March 09, 202

Revised April 15, 2021

Accepted April 30, 2021

Available online August 25, 2021

Kata Kunci:

Discovery Learning, Hasil

Belajar, Powerpoint

Keywords:

Discovery Learning, Learning

Outcomes, Powerpoint

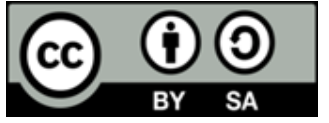

This is an open access article under the CC BY-SA license.

Copyright (C) 2021 by Author. Published by Universitas Pendidikan Ganesha.

\begin{abstract}
A B S T R A K
Pembelajaran kurang menggunakan media yang bisa menarik perhatian siswa serta model yang belum inovatif sesuai karakteristik siswa, sehingga membuat siswa kurang aktif dalam mengikuti pembelajaran. Rendahnya motivasi siswa dalam belajar berdampak pada hasil belajar IPS dan keaktifan siswa kelas IVB dalam belajar belum optimal. Penelitian ini bertujuan untuk mengetahui peningkatan hasil belajar IPS melalui model discovery learning berbantuan media powerpoint. Subjek penelitian yaitu siswa kelas IVB yang berjumlah 44 orang. Data dikumpulkan menggunakan metode tes pilihan ganda dengan jumlah soal 15 butir. Data dianalisis menggunakan statistik deskriptif kuantitatif yaitu dengan mencari mean, median, modus, daya serap, dan ketuntasan belajar. Hasil penelitian menunjukkan adanya peningkatan hasil belajar IPS pada siswa kelas IV B. Hal ini terlihat hasil belajar siswa prasiklus dengan nilai rata-rata 69,25 dan ketuntasan belajar $54,55 \%$ pada kategori rendah. Hasil belajar pada siklus I nilai rata-rata 74,11 dan ketuntasan belajar $68,18 \%$ dengan kategori cukup. Pada siklus II rata-rata sebesar 81,77 dan ketuntasan belajar $81,80 \%$ dengan kategori tinggi. Dapat disimpulkan bahwa penerapan model discovery learning berbantuan media powerpoint dapat meningkatkan hasil belajar siswa kelas IVB. Penelitian ini berimplikasi pada penerapan model discovery learning berbantuan media powerpoint yaitu, meningkatkan keaktifan siswa dalam menemukan sendiri pengetahuannya yang membuat pembelajaran lebih bermakana, belajar mandiri, dan tidak mudah dilupakan siswa.
\end{abstract}

\section{A B S T R A C T}

Less learning uses media that can attract student' attention, as well as models that have not been innovative according to student characteristics so that students are active in participating in learning. The low motivation of students in learning which has an impact on social studies learning outcomes for class IVB students is not optimal. Classroom action research aims to determine the improvement of social sciences content learning outcomes through discovery learning models that is assisted by power point media. The research subjects were students of class IVB, totaling 44 people. Social Sciences learning outcomes data were collected using the multiple choice test with a total of 15 questions. Data were analyzed using quantitative descriptive statistical analysis techniques, namely by finding the mean, median, mode, absorption, and learning completeness. The results showed an increase in social studies learning outcomes in fourth grade students. This can be seen from the results of precycle learning with an average of 69,25 and $54,55 \%$ learning completeness in the low category. Outcome student learning cycle l averaged 74,11 and learning completeness was $68.18 \%$ in the sufficient category. On cycle II averaged 81.77 and learning completeness was $81,80 \%$ in the high category. Can be concluded that the it can be concluded that the application of the discovery learning model which is assisted by power point media can improve the learning outcomes of social sciences for grade IV B students. This research has implications for the application of the powerpoint assisted discovery learning model, namely, increasing student activity in discovering their own knowledge which makes learning more meaningful, independent learning and not easily forgotten by students. 


\section{PENDAHULUAN}

Ilmu Pengetahuan Sosial (IPS) merupakan salah satu muatan pelajaran yang diajarkan mulai jenjang pendidikan dasar sampai pendidikan menengah. IPS merupakan ilmu yang mengkaji, mempelajari, menelaah, serta menganalisis realita kondisi sosial yang ada di lingkungan siswa untuk membangun serta merefleksikan kemampuan siswa dalam kehidupan bermasyarakat yang selalu berubah dan berkembang secara terus menerus dan nantinya melahirkan warga negara yang baik dan bertanggung jawab terhadap bangsa dan negaranya (Aryawan et al., 2018; Dharin et al., 2020). Di masa yang akan datang, siswa akan menghadapi tantangan berat karena kehidupan masyarakat global selalu mengalami perubahan terus-menerus. Oleh karena itu, pelajaran IPS dirancang untuk mengembangkan pengetahuan, pemahaman, dan kemampuan analisis terhadap kondisi sosial masyarakat dalam memasuki kehidupan bermasyarakat yang dinamis. Tujuan utama mengajarkan ilmu pengetahuan sosial pada siswa adalah menjadikan warga negara yang baik, melatih kemampuan berpikir matang untuk menghadapi permasalahan social, dan agar mewarisi dan melanjutkan budaya bangsanya (Rifky, 2017). Peranan IPS sangat penting untuk mendidik siswa mengembangkan pengetahuan, sikap, dan keterampilan agar dapat mengambil bagian secara aktif dalam kehidupannya kelak sebagai anggota masyarakat dan warga yang baik (Anggreni, 2018; Suryadewi et al., 2020).

Pendidikan IPS di sekolah dasar saat ini dihadapkan pada upaya peningkatan kualitas Pendidikan, khususnya kualitas sumber daya manusia, sehingga eksistensi pendidikan IPS benar-benar dapat mengembangkan pemahaman konsep dan keterampilan berpikir kritis. Ruang lingkup kompetensi pengetahuan IPS di sekolah dasar diabdikan dalam 3 lingkup dimensi sosial, yaitu menekankan pada perilaku terampil, dan rasionalitas (Nilayuniarti et al., 2020). IPS bersumber pada social life yang benarbenar dialami dan disaring berdasarkan konsep-konsep ilmu social, kemudian diaplikasikan pada kegiatan proses pembelajaran. Dengan demikian, dapat dikatakan bahwa ilmu pengetahuan sosial merupakan ilmu yang memiliki keterkaitan terhadap berbagai aspek kehidupan. Cakupan dalam pembelajaran ilmu pengetahuan sosial pada jenjang sekolah dasar sangat luas karena merupakan gabungan dari cabang ilmu-ilmu sosial (Sumitro et al., 2017). Tidak hanya mementingkan aspek kognitif, ilmu pengetahuan sosial juga mementingkan aspek afektif serta psikomotor (Ningtyas \& Wuryani, 2017) berdasarkan hal tersebut, IPS tidak kalah penting dari ilmu pengetahuan lain karena dapat mempersiapkan siswa untuk terjun dalam kehidupan sosial. Muatan pelajaran IPS di sekolah dasar mencakup persoalan manusia dan lingkungannya yang tidak dapat difokuskan melalui hafalan semata. Namun, diperlukan pemahaman, pengamatan, dan penerapan dalam kehidupan sehari-hari. Hal ini menuntut pengetahuan kognitif siswa untuk dapat memahami dan menerapkan ilmu pengetahuannya dalam kehidupan sehari-hari.

Berdasarkan pengamatan yang telah dilaksanakan dalam proses pembelajaran IPS, guru belum optimal dalam mengintegrasikan teknologi dalam menginovasikan media pembelajaran. Pada proses pembelajaran hanya menggunakan buku tanpa adanya media yang bisa menarik perhatian siswa dalam pembelajaran di kelas. Siswa masih takut-takut menyampaikan pendapatnya, baik dalam bertanya maupun menjawab pertanyaan yang diajukan oleh guru. Hal itu terjadi karena dianggap jika siswa menjawab atau bertanya akan disalahkan, maka siswa memilih untuk diam. Selain itu, siswa sering merasa bosan belajar karena pembelajaran yang dikemas kurang menarik dan kurangnya media pembelajaran yang dapat membangkitkan motivasi belajar siswa. Hasil belajar siswa cenderung rendah pada muatan IPS. Masalah tersebut sejalan dengan penelitian sebelumnya yang menyatakan bahwa kurangnya motivasi siswa dalam belajar serta penggunaan strategi pembelajaran yang dilakukan guru kurang tepat, selain itu pembelajaran yang digunakan masih bersifat teacher center sehingga siswa menjadi pasif (Astuti et al., 2018; Muhammad \& Hupiah, 2019). Penelitian yang menyatakan jika siswa tidak aktif maka proses pembelajaran tidak akan berjalan dengan optimal (Marhayani \& Wulandari, 2020). Kurangnya guru menerapkan suatu inovasi yang kreatif dalam pembelajaran . Inovasi yang kreatif bisa menarik perhatian siswa untuk meningkatkan hasil belajarnya (Lidiana et al., 2018). Proses pembelajaran yang seperti ini dapat mengakibatkan pembelajaran kurang bermakna. Pembelajaran yang tidak dikemas dengan kreatif membuat motivasi siswa dalam mengikuti pembelajaran menurun yang mengakibatkan hasil belajar siswa kurang optimal. Berdasarkan beberapa permasalahan yang ditemukan, perlu adanya inovasi dalam pembelajaran tersebut. Salah satu inovasi yang dapat dilakukan untuk mengatasi permasalahan tersebut, yaitu dengan menerapkan model discovery learning. Model discovery learning memiliki begitu banyak keunggulan yang dapat menumbuhkan kreativitas dan keaktifan siswa (Pane et al., 2020).

Model discovery learning menitikberatkan pada peran aktif siswa dalam pembelajaran, sedangkan guru sebagai fasilitator atau membantu siswa menemukan dan mengonstruksikan pengetahuan yang dipelajari (Lieung, 2019). Discovery learning mengajak siswa untuk menggunakan kemampuannya secara maksimal dalam mencari dan menemukan sesuatu, baik itu berupa benda, 
manusia, maupun peristiwa secara sistematis, logis, kritis, dan analitis yang kemudian dapat dirumuskan sendiri oleh siswa dengan penuh percaya diri (Lidiana et al., 2018; Patandung, 2017). Sependapat dengan hal tersebut Astari et al., (2018) menyatakan bahwa model discovery learning merupakan proses pembelajaran yang diperoleh melalui pengamatan atau percobaan dan menciptakan suasana pembelajaran baru yang dapat membuat peserta didik belajar aktif untuk menemukan pengetahuan sendiri sehingga hasil belajar siswa dapat meningkat. Berdasarkan hal tersebut dapat disimpulkan bahwa model discovery learning adalah model pembelajaran untuk meningkatkan keaktifan siswa dalam menemukan pengetahuan yang dipelajari dengan kemampuannya sendiri secara maksimal. Model discovery learning mampu meningkatkan kemampuan dan kepercayaan diri siswa untuk berperan menghadapi masalah-masalah yang diambil dari materi pembelajaran, sehingga lebih mudah dipahami dan lebih lama diingat siswa yang dapat mendukung peningkatan aktivitas belajar dan hasil belajar siswa (Muhammad \& Hupiah, 2019).

Penerapan model discovery learning ini perlu dilengkapi dengan sebuah media pembelajaran untuk menjadikan pembelajaran semakin menarik. Media pembelajaran yang digunakan, yaitu powerpoint yang berperan penting dalam menyampaikan materi pembelajaran bagi siswa. Microsoft powerpoint merupakan salah satu program untuk membuat presentasi dengan fasilitas yang ada dan dapat digunakan untuk membuat media pembelajaran (Suprapti, 2016). Powerpoint memiliki kemampuan yang sangat baik dalam menyajikan sebuah materi presentasi karena dapat mengolah teks, gambar, warna, tampilan, dan animasi-animasi yang disesuaikan dengan kebutuhan siswa. Keunggulan penggunaan media power point adalah dapat membuat penyampaian materi pembelajaran menjadi semakin menarik dan dapat diingat baik oleh siswa karena pemaparan materi disertai dengan gambar-gambar serta animasi (Radyana et al., 2017). Media powerpoint merupakan pilihan yang tepat digunakan pada pelajaran IPS dalam menampilkan gambar serta video mengenai materi pembelajaran. Dengan demikian, siswa mampu memahami dengan jelas materi yang disampaikan. Powerpoint digunakan sebagai media yang menambah daya tarik siswa dalam mengikuti pembelajaran, sehingga siswa mampu memahami materi yang diajarkan dengan lebih mudah serta diharapkan mampu meningkatkan hasil belajar IPS siswa (Astawa, 2019). Berdasarkan uraian tersebut, maka penelitian ini bertujuan untuk meningkatkan hasil belajar IPS dengan menerapkan model discovery learning berbantuan media powerpoint pada siswa kelas IV B SDN 21 Pemecutan.

\section{METODE}

Penelitian yang dilaksanakan adalah termasuk jenis penelitian tindakan kelas. Subjek penelitian ini adalah siswa kelas IVB di SD Negeri 21 Pemecutan tahun ajaran 2020/2021 yang berjumlah 44 orang, yang terdiri dari 18 siswa perempuan dan 26 siswa laki-laki. Data yang diperoleh diupayakan menyangkut tindakan yang akan dijadikan alternatif guna memperbaiki kondisi yang dihadapi. Oleh sebab itu, ditentukan objek penelitian ini adalah hasil belajar siswa dengan menggunakan model discovery learning berbantuan media powerpoint pada siswa IV B SD Negeri 21 Pemecutan tahun ajaran 2020/2021. Penelitian ini dilaksanakan dalam pola siklus, yang artinya siklus selanjutnya akan ditentukan berdasarkan siklus sebelumnya sampai diperoleh hasil yang diharapkan dengan mencapai kriteria keberhasilan yang telah ditetapkan. Setiap siklus terdiri dari empat tahapan, yaitu merencanakan, melakukan tindakan, pengamatan, serta refleksi. Tahapan penelitian seperti pada Gambar 1.

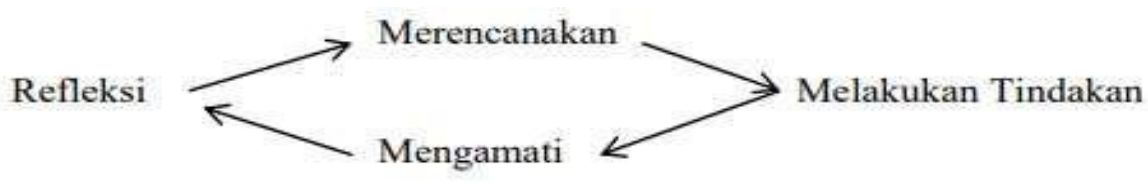

Gambar 1. Tahap dalam PTK (Wardani, 2020)

Penelitian ini menggunakan teknik pengumpulan data dengan metode tes. Tes dalam penelitian ini digunakan untuk mengukur hasil belajar IPS siswa. Teknik tes dalam penelitian ini yaitu post tes yang dilaksanakan dua kali, yaitu post tes siklus I dan post tes siklus II. Post tes siklus I diberikan setelah pertemuan ke empat dari siklus I berakhir, sedangkan post tes siklus II diberikan setelah pertemuan ke empat dari siklus II berakhir. Tujuan pemberian post tes pada akhir siklus yaitu untuk mengetahui hasil belajar IPS siswa setelah diberikan tindakan atau perlakukan. Instrumen pengumpulan data yang digunakan pada penelitian ini berupa soal pilihan ganda dengan empat alternatif jawaban yang dipilih siswa (a, b, c, dan d) diberikan kepada siswa yang berjumlah 15 butir soal. Setiap butir item akan 
diberikan skor 1 untuk siswa yang menjawab benar dan skor 0 untuk siswa yang menjawab salah (jawaban dicocokkan dengan kunci jawaban). Soal yang disusun disesuaikan dengan mengikuti jenjang Taksonomi Bloom revisi oleh Anderson dengan ranah kognitif. Untuk menentukan secara jelas ruang lingkup penelitian dan sebagai petunjuk dalam menulis butir instrumen, harus ditentukan kisi-kisi dari instrumen yang akan disusun. Kisi-kisi instrumen disusun berdasarkan objek pelaksanaan tindakan yang dilakukan di kelas. Adapun kisi-kisi instrumen dapat dilihat pada Tabel 1.

Tabel 1. Kisi-kisi Instrumen

\begin{tabular}{|c|c|c|}
\hline Kompetensi Dasar & Indikator & $\begin{array}{l}\text { Tingkat } \\
\text { Kognitif }\end{array}$ \\
\hline \multirow{13}{*}{$\begin{array}{lr}3.2 & \text { Mengidentifikasi } \\
\text { keragaman } & \text { sosial, } \\
\text { ekonomi, } & \text { budaya, } \\
\text { etnis, dan } & \text { agama di } \\
\text { provinsi } & \text { setempat } \\
\text { sebagai } & \text { identitas } \\
\text { bangsa Indonesia serta } \\
\text { hubungannya dengan } \\
\text { karakteristik ruang. }\end{array}$} & 3.2.1 Menemukan keberagaman yang & \multirow{2}{*}{$\mathrm{C} 4$} \\
\hline & terdapat di lingkungan masyarakat & \\
\hline & $\begin{array}{l}\text { 3.2.2Menganalisis faktor-faktor penyebab keberagaman yang } \\
\text { terdapat di lingkungan masyarakat }\end{array}$ & $\mathrm{C} 4$ \\
\hline & 3.2.3 Mengidentifikasi keragaman bahasa daerah. & $\mathrm{C} 1$ \\
\hline & 3.2.4 Mengaitkan bahasa daerah dengan asal daerah & $\mathrm{C} 4$ \\
\hline & 3.2.5 Mengidentifikasi keunikan rumah adat & $\mathrm{C} 1$ \\
\hline & 3.2.6 Membandingkan keunikan rumah adat & $\mathrm{C} 5$ \\
\hline & $\begin{array}{l}\text { 3.2.7 Mengidentifikasi daerah asal dengan keunikan } \\
\text { adat Indonesia }\end{array}$ & $\mathrm{C} 1$ \\
\hline & 3.2.8 Mebandingkan keunikan pakaian adat & $\mathrm{C} 5$ \\
\hline & $\begin{array}{l}\text { 3.2.9 Menganalisis kegiatan ekonomi di } \\
\text { Indonesia }\end{array}$ & $\mathrm{C} 4$ \\
\hline & $\begin{array}{l}\text { 3.2.10 Membandingkan kegiatan ekonomi di } \\
\text { Indonesia }\end{array}$ & $\mathrm{C} 5$ \\
\hline & $\begin{array}{l}\text { 3.2.11 Menganalisis kegiatan ekonomi di } \\
\text { lingkungan sekitar }\end{array}$ & $\mathrm{C} 4$ \\
\hline & $\begin{array}{l}\text { 3.2.12 Membandingkan kegiatan ekonomi di } \\
\text { lingkungan sekitar }\end{array}$ & $\mathrm{C} 5$ \\
\hline
\end{tabular}

Data hasil belajar terkumpul maka akan dilakukan analisis terhadap data dengan teknik analisis yang digunakan adalah metode analisis statistik deskriptif kuantitatif. Metode analisis deskriptif kuantitatif merupakan suatu cara pengolahan data yang dilakukan dengan jalan menyusun secara sistematis dalam bentuk angka-angka dan atau persentase mengenai objek yang diteliti, sehingga diperoleh kesimpulan umum (Agung, 2010). Analisis data hasil belajar siswa menggunakan analisis deskriptif kuantitatif yaitu dengan mencari mean, median, modus, daya serap, dan ketuntasan belajar. Hasil analisis yang diperoleh berdasarkan mean dan ketuntasan belajar yang dikonversikan ke dalam PAP skala lima. Pedoman yang dipergunakan sesuai dengan PAP skala lima sesuai pada Tabel 2.

Tabel 2. Kriteria Penilaian Acuan Patokan (PAP) Skala Lima Tentang Hasil Belajar Siswa

\begin{tabular}{lc}
\hline Tingkat penguasaan & Kategori \\
\hline $85 \%-100 \%$ & Sangat Tinggi \\
$70 \%-84 \%$ & Tinggi \\
$55 \%-69 \%$ & Cukup \\
$40 \%-54 \%$ & Rendah \\
$0-39 \%$ & Sangat Rendah \\
\hline
\end{tabular}

Keberhasilan suatu penelitian dapat dilihat dari kemajuan hasil belajar yang dicapai oleh siswa sesuai dengan KKM pada pelajaran IPS yaitu 69 yang sudah ditetapkan sekolah. Adapun indikator keberhasilan merupakan acuan tolak ukur untuk mengetahui keberhasilan tindakan yang telah dilakukan. Penelitian ini dikatakan berhasil apabila nilai rata-rata kelas dan daya serap $\geq 70$ ketuntasan belajar mencapai $\geq 80 \%$ yang berada pada kategori tinggi. 


\section{HASIL DAN PEMBAHASAN}

Hasil

Hasil belajar siswa pada prasiklus dalam penelitian ini menunjukkan kondisi awal dan sesudah diadakannya penelitian pada siklus I dan siklus II. Hasil prasiklus, siklus I, dan siklus II dapat dilihat pada Tabel 3.

Tabel 3. Rekapitulasi Hasil Belajar Prasiklus, Siklus I, Siklus II

\begin{tabular}{lccc}
\hline Aspek & Prasiklus & Siklus 1 & Siklus II \\
\hline Jumlah Seluruh Siswa & 44 & 44 & 44 \\
Jumlah Nilai & 3047 & 3261 & 3598 \\
KKM & 69 & 69 & 69 \\
Mean & 69,25 & 74,11 & 81,77 \\
Median & 68,67 & 75,50 & 83,10 \\
Modus & 68,20 & 76,87 & 84,10 \\
Daya Serap & $69,25 \%$ & $74,11 \%$ & $81,77 \%$ \\
Nilai Tertinggi & 87 & 100 & 100 \\
Nilai Terendah & 47 & 47 & 60 \\
Jumlah Siswa Tuntas & 20 & 30 & 36 \\
Jumlah Siswa Tidak Tuntas & 24 & 14 & 8 \\
Persentase Ketuntasan Belajar & $54,55 \%$ & $68,18 \%$ & $81,80 \%$ \\
\hline
\end{tabular}

Berdasarkan tabel 3 hasil belajar pada prasiklus dalam penelitian ini diketahui bahwa kondisi awal pada pembelajaran adalah sebagai berikut. Hasil belajarnya belum mencapai KKM yang telah ditentukan oleh sekolah. Merujuk pada hasil Penilaian Akhir Semester (PAS) ganjil tahun ajaran 2020/2021 pada pelajaran IPS ditemukan lebih banyak siswa yang tidak tuntas berdasarkan KKM yang telah ditentukan yaitu 69. Hasil belajar IPS pada prasiklus yang dikonversikan ke dalam PAP skala lima masih tergolong rendah. Oleh karena itu, diadakan perbaikan dengan menerapkan model discovery learning berbantuan media powerpoint.

Hasil belajar IPS siklus I yang telah didapatkan, selanjutnya dikonversikan ke dalam PAP skala lima, maka hasil belajar siswa pada siklus I tergolong cukup. Hasil belajar siswa pada muatan IPS mengalami peningkatan jika dibandingkan dengan data awal hasil belajar siswa. Data hasil belajar siswa menunjukkan belum memenuhi kriteria keberhasilan penelitian. Oleh karena itu, perlu adanya tindakan perbaikan pada pelaksanaan siklus II, sehingga diharapkan hasil belajar siswa dapat meningkat. Setelah hasil belajar IPS yang telah didapatkan dikonversikan ke PAP skala lima, maka tingkat hasil belajar siswa pada siklus II tergolong tinggi. Merujuk dari hasil tersebut, maka penelitian dinyatakan sudah berhasil karena sudah sesuai dengan ketuntasan belajar yang ditetapkan. Berdasarkan gambaran data hasil belajar siswa pada muatan IPS, hasil belajar siswa telah mengalami peningkatan jika dibandingkan dengan data pada siklus I. Hasil peningkatan penelitian dari prasiklus, siklus I, dan siklus II mengenai hasil belajar IPS siswa kelas IV B dapat dilihat pada Tabel 4.

Tabel 4. Peningkatan Hasil Belajar IPS Siswa Kelas IV B Tahun Ajaran 2020/2021

\begin{tabular}{lccccc}
\hline \multicolumn{1}{c}{ Deskripsi } & Prasiklus & Peningkatan & Siklus I & Peningkatan & Siklus II \\
\hline Rata-rata nilai siswa & 69,25 & 4,86 & 74,11 & 7,66 & 81,77 \\
Ketuntasan Belajar & $54,55 \%$ & 13,63 & $68,18 \%$ & 13,62 & $81,80 \%$ \\
Katagori PAP & Rendah & - & Cukup & - & Tinggi \\
\hline
\end{tabular}

Dari tabel 4 dapat diketahui bahwa nilai daya serap 69,25\% dan nilai rata-rata yang diperoleh siswa kelas IV B pada muatan pelajaran IPS adalah 69,25. Jumlah siswa yang tuntas lebih sedikit dibanding siswa yang belum tuntas. Dari jumlah 44 siswa, hanya 20 berhasil mencapai KKM, 24 siswa belum mencapai KKM, sehingga persentase ketuntasan belajar yang diperoleh yaitu 54,55\%. Setelah hasil belajar siswa dikonversikan ke dalam PAP skala lima, maka tingkat hasil belajar siswa pada prasiklus masih tergolong rendah. Dengan melihat hasil dari data tersebut perlu adanya tindakan perbaikan dalam pembelajaran melalui model discovery learning berbantuan media power point, sehingga diharapkan hasil belajar siswa dapat meningkat.

Pada siklus I terdiri dari empat tahapan meliputi merencanakan, melaksanakan, mengamati dan refleksi. Pelaksanaan pada siklus I dilakukan selama tiga kali pertemuan pelaksanaan tindakan dengan pembelajaran melalui model discovery learning berbantuan media powerpoint. Data yang diperoleh 
berdasarkan data nilai hasil belajar siswa. Hasil belajar siswa pada siklus I menunjukkan bahwa skor tertinggi adalah 100 dan skor terendah adalah 47. Diperoleh hasil mean yaitu sebesar 74,11, median yaitu sebesar 75,50, modus yaitu sebesar 76,87. Berdasarkan hasil pelaksanaan siklus I pembelajaran dengan menggunakan model pembelajaran pada mata pelajaran muatan pelajaran IPS di kelas IV B SD Negeri 21 Pemecutan diperoleh hasil penilaian post test hasil belajar yang telah dilakukan dapat diketahui bahwa pada siklus I diperoleh nilai daya serap 74,11 \% dan nilai rata-rata siswa yaitu 74,11. Dari 44 siswa, 14 siswa yang tidak tuntas karena nilai yang diperoleh belum mencapai KKM yang diharapkan. Nilai KKM yang ditentukan oleh sekolah yaitu 69, sedangkan persentase ketuntasan belajar siswa yang diperoleh hanya sebesar $68,18 \%$.

Setelah hasil belajar siswa dikonversikan ke dalam PAP skala lima, maka tingkat hasil belajar siswa pada siklus I tergolong cukup. Gambaran data hasil belajar siswa pada muatan IPS mengalami peningkatan jika dibandingkan dengan data awal hasil belajar siswa. Walaupun demikian, data hasil belajar siswa menunjukkan belum memenuhi kriteria keberhasilan penelitian. Dilihat hasil data yang telah disusun, perlu adanya tindakan perbaikan dalam pembelajaran melalui model discovery learning berbantuan media powerpoint, sehingga diharapkan hasil belajar siswa dapat meningkat. Refleksi berdasarkan hasil tindakan siklus I dapat dijabarkan sebagai berikut. 1) Sebagian siswa tidak dapat mengikuti google meet karena terkendala HP dan kuota; 2) Kendala pada sinyal yang membuat suara tidak dapat terdengar dengan jelas baik suara guru yang tidak didengar oleh siswa atau suara siswa ketika berpendapat, sehingga ini membuat hasil rekaman kurang bagus; 3) Siswa belum terbiasa belajar dengan gaya belajar daring, sehingga proses pembelajaran belum terlaksana secara efektif; 4) Sebagian siswa belum berani mengemukakan pendapatnya. Setelah ada satu siswa yang mengemukakan pendapat, siswa yang lain ikut menyampaikan pendapatnya; 5) Guru harus menunjuk salah siswa untuk memberikan pendapat untuk memancing siswa yang lain berani berpendapat.

Mengacu pada kekurangan yang dihadapi pada siklus I guru merancang perbaikan tindakan untuk selanjutnya diterapkan pada siklus II adalah membagikan video pembelajaran, bahan ajar, LKPD, tes evaluasi pembelajaran ke WAG agar siswa yang tidak dapat mengikuti kegiatan google meet dapat membaca bahan ajar, menyimak video pembelajaran, mengerjakan LKPD, tes evaluasi dibimbing oleh guru melalui Whatsapp Group ataupun melalui Whatsapp pribadi guru serta pemberian materi dan tugas secara luring. Selanjutnya, memberikan motivasi kepada siswa untuk berani mengungkapkan pendapatnya dan agar lebih bersemangat untuk mengikuti pembelajaran daring. Pada siklus II terdiri dari empat tahapan meliputi merencanakan, melaksanakan, mengamati dan refleksi. Pelaksanaan pada siklus II dilakukan selama tiga kali pertemuan pelaksanaan tindakan dengan pembelajaran melalui model discovery learning berbantuan media power point. Setelah dilaksanakan kegiatan pembelajaran, maka diperoleh data hasil belajar siswa. Data yang diperoleh data nilai hasil belajar siswa. Data yang diperoleh untuk dianalisis pada siklus II adalah skor siswa pada tes akhir yang jumlahnya 15 soal. Hasil belajar siswa pada siklus II menunjukkan bahwa skor tertinggi adalah 100 dan skor terendah adalah 60 . Diperoleh hasil mean, yaitu sebesar 81,77, median, yaitu sebesar 83,16 modus yaitu sebesar 84,10.

Berdasarkan hasil pelaksanaan siklus II pembelajaran dengan menggunakan model pembelajaran pada mata pelajaran IPS diperoleh hasil penilaian post test hasil belajar yang telah dilakukan. Dari data yang telah disusun dapat diketahui bahwa dengan model pembelajaran model discovery learning berbantuan media powerpoint pada siklus II diperoleh daya serap 81,77\% dan nilai rata-rata siswa yaitu 81,77. Dari 44 siswa, 8 siswa yang tidak tuntas karena nilai yang diperoleh belum mencapai KKM yang diharapkan. Nilai KKM yang ditentukan oleh sekolah yaitu 69, sedangkan persentase ketuntasan belajar siswa yang diperoleh sebesar 81,80\%. Setelah hasil belajar siswa dikonversikan ke dalam PAP skala lima, maka tingkat hasil belajar siswa pada siklus II tergolong tinggi. Gambaran data hasil belajar siswa pada muatan IPS mengalami peningkatan jika dibandingkan dengan data pada siklus I. Dengan demikian pada siklus II kriteria keberhasilan penelitian sudah tercapai nilai rata-rata kelas $\geq 70$ dan ketuntasan belajar mencapai $\geq 80 \%$ yang berada pada kategori tinggi. Setelah menerapkan pembelajaran model discovery learning berbantuan media powerpoint pada muatan IPS di kelas IV B SD Negeri 21 Pemecutan Tahun Ajaran 2020/2021 ternyata kendala yang terjadi pada siklus I relatif sudah teratasi pada siklus II. Hal ini dapat dilihat dari hasil belajar IPS pada siklus II sudah melampaui kriteria keberhasilan penelitian. Oleh karena itu, penelitian dapat dihentikan pada siklus II.

Berdasarkan hasil dan pembahasan penelitian dapat disimpulkan bahwa penerapan model discovery learning berbantuan media powerpoint dapat meningkatkan hasil belajar IPS di kelas IV B SD Negeri 21 Pemecutan Tahun Ajaran 2020/2021. Keberhasilan yang diperoleh pada penelitian ini didasari oleh beberapa faktor yaitu sebagai berikut. Pertama, dengan model discovery learning guru tidak langsung memberikan hasil akhir atau kesimpulan dari materi yang disampaikannya, namun siswa diberi kesempatan mencari dan menemukan sendiri hasil data tersebut. Hal ini dapat mengakibatkan proses pembelajaran lebih bermakna, sehingga siswa lebih mudah mengingat dan memahami materi yang 
dibahas. Hal ini juga berdampak pada peningkatan hasil belajar siswa karena siswa terlibat langsung ketika proses pembelajaran. Di samping itu, akan terjadi peningkakan potensi siswa dalam upaya memecahkan masalah dan mampu memperkuat konsep yang sudah dimilikinya. Kedua, model discovery learning dapat meningkatkan hasil belajar siswa di sekolah dasar karena model ini dapat mengubah kondisi belajar yang pasif menjadi aktif dan menuntut siswa untuk menemukan sendiri pengetahuan yang dipelajari. Dengan demikian, pembelajaran mudah diikuti oleh siswa dan pembelajaran lebih bermakna. Penerapan model pembelajaran discovery learning membuat siswa berpartisipasi aktif dalam proses pembelajaran menemukan pengetahuannya sendiri dengan guru berperan sebagai fasilitator untuk mengatur jalannya pembelajaran (Ana, 2019). Model discovery learning memberi kesempatan kepada siswa untuk menjadi seorang problem solver atau ilmuwan kecil yang membuat siswa dapat menemukan jati diri, mempelajari konsep dengan bahasanya sendiri dan siswa menjadi lebih mandiri. Ketiga, model pembelajaran discovery learning membantu siswa untuk dapat memotivasi dirinya, memperkuat pengetahuannya sendiri, serta membuat pembelajaran yang dilakukan akan diingat oleh siswa sepanjang masa, sehingga hasil yang ia dapat tidak mudah dilupakan (Rahmayani, 2019). Penggunaan media powerpoint dalam pembelajaran sangat membantu siswa dalam menarik minat belajar dengan tampilan yang menarik. Media yang digunakan berupa gambar atau video yang nantinya bisa membantu siswa memperkuat ingatannya terhadap materi pembelajaran, sehingga dapat meningkatkan hasil belajarnya. Hasil belajar dapat menunjukkan tingkat keberhasilan siswa dalam mempelajari materi pelajaran di sekolah yang dinyatakan dalam bentuk skor yang diperoleh dari hasil tes dari sejumlah materi pelajaran.

Belajar IPS untuk siswa SD pada dasarnya bertujuan untuk membuat siswa mampu memahami kehidupan sosial yang ada di lingkungannya. Karena pentingnya makna pembelajaran IPS, maka diharapkan hasil belajar IPS harus mampu diraih secara optimal oleh siswa. Pendidikan IPS tidak hanya memberikan ilmu pengetahuan semata, tetapi harus berorientasi pada pengembangan keterampilan berpikir kritis, sikap, dan kecakapan-kecakapan dasar siswa yang berpijak pada kenyataan kehidupan sosial kemasyarakatan sehari-hari dan memenuhi kebutuhan bagi kehidupan sosial siswa di masyarakat (Ratnadewi, 2018). Temuan dalam penelitian ini menunjukkan penerapan tindakan yang dilakukan sejalan dengan teori yang digunakan sebagai acuan pelaksanaan penelitian. Selain itu, persamaan hasil penelitian ini dengan penelitian sebelumnya yang relevan telah memperkuat hasil penelitian yang diperoleh. Hal ini didukung oleh penelitian yang dilakukan oleh (Jayadiningrat et al., 2019), yaitu hasil analisis penerapan model pembelajaran discovery learning dapat meningkatkan aktivitas belajar siswa. Hal ini terlihat dari adanya peningkatan persentase rata-rata aktivitas belajar siswa sebesar $10 \%$ dari 74\% dalam kategori cukup aktif pada siklus I menjadi 84\% atau berada pada kategori sangat aktif pada siklus II. Hal ini terlihat dari adanya peningkatan persentase rata-rata rata-rata hasil belajar siswa sebesar 13\% dari 75\% dalam kategori cukup baik pada siklus I menjadi $88 \%$ atau berada pada kategori sangat baik pada siklus II.

Di samping itu, dengan penelitian melalui model discovery learning, siswa yang berperan aktif dalam menemukan dan mencari sendiri sesuatu yang dibutuhkan dalam proses pembelajaran. Siswa tidak lagi menganggap pembelajaran membosankan melainkan merupakan sesuatu hal yang menyenangkan dengan menemukan sendiri, menyelidiki sendiri, maka hasil yang akan diperoleh akan tahan lama dalam ingatan, tidak akan mudah dilupakan siswa (Astuti et al., 2018; Basri et al., 2018). Hasil penelitian melalui penerapan model discovery learning, siswa aktif bertanya ataupun menjawab pertanyaan dari guru, aktif dalam diskusi kelompok, dan pemecahan masalah serta siswa menjadi lebih memahami materi yang diajarkan melalui penemuan dan pencarian (Ana, 2019; Salmi, 2019; Supanti, 2019). Penelitian ini berimplikasi peningkakan keaktifan siswa dalam menemukan sendiri pengetahuannya yang membuat pembelajaran lebih bermakana, belajar mandiri, dan tidak mudah dilupakan siswa. Implikasi yang telah dipaparkan tentu masih memiliki beberapa kekurangan mengingat masih adanya keterbatasan dalam penelitian ini yaitu pembelajaran daring membuat keterbatasan mengungkap keterampilan pemecahan masalah yang tentunya akan berimplikasi pada hasil belajar siswa. Berdasarkan hal tersebut, direkomendasikan agar pada penelitian berikutnya diupayakan pembelajaran dapat dikembangkan dengan berbagai platfrom pembelajaran daring yang lebih beragam, bervariasi, dan menyenangkan.

\section{SIMPULAN}

Penerapan model discovery learning berbantuan media powerpoint dapat meningkatkan hasil belajar pada muatan IPS. Model discovery learning berbantuan media powerpoint melibatkan seluruh siswa dalam pembelajaran diharapkan dapat meningkatkan pemahaman siswa, sehingga pembelajaran dapat lebih bermakna bagi siswa, dapat meningkatkan kemampuan pemecahan masalah siswa, mengarahkan kegiatan siswa untuk belajarnya secara mandiri dengan melibatkan kognitif, motivasinya, 
meningkatkan kemampuan berkomunikasi, dan menambah kepercayaan diri melalui proses menemukan sendiri pengetahuan yang dibahas.

\section{DAFTAR PUSTAKA}

Agung, A. A. G. (2010). Pengantar Evaluasi Pendidikan. Fakultas Ilmu Pendidikan Undiksha Singaraja.

Ana, N. Y. (2019). Penggunaan Model Pembelajaran Discovery Learning dalam Peningkatan Hasil Belajaran Siswa di Sekolah Dasar. Pedagogi: Jurnal Ilmu Pendidikan, 18(2), 56. https://doi.org/10.24036/fip.100.v18i2.318.000-000.

Anggreni, N. K. P. (2018). Pengaruh Model Pembelajan Picture and Picture terhadap Penguasaan Kompetensi Pengetahuan IPS Siswa Kelas V SD Gugus Raden Ajeng Kartini. Jurnal Ilmu Pendidikan, 1(1), 41-47. https://jayapanguspress.penerbit.org/index.php/cetta/article/view/45.

Aryawan, R., Sudatha, I. G. W., \& Sukmana, A. I. W. I. Y. (2018). Pengembangan E-Modul Interaktif Mata Pelajaran IPS di SMP Negeri 1 Singaraja. Urnal EDUTECH Universitas Pedidikan Ganesha, 6, 180191. http://dx.doi.org/10.23887/jeu.v6i2.20290.

Astari, F. A., Suroso, S., \& Yustinus, Y. (2018). Efektifitas Penggunaan Model Discovery Learning dan Model Problem Based Learning terhadap Hasil Belajar IPA Siswa Kelas 3 SD. Jurnal Basicedu, 2(1), 1-10. https://doi.org/10.31004/basicedu.v2i1.20.

Astawa, A. P. I. M. T. (2019). Pengaruh Model Pembelajaran Kooperatif Tipe Make A Match Berbantuan Media Powerpoint terhadap Hasil Belajar IPA. MIMBAR PGSD Undiksha, 3(1), 99-106. https: //doi.org/10.26858/publikan.v10i3.15159.

Astuti, T. I., Idrus, I., \& Yennita, Y. (2018). Penerapan Model Pembelajaran Discovery Learning untuk Meningkatkan Hasil Belajar pada Materi Biologi Siswa SMP. Diklabio: Jurnal Pendidikan Dan Pembelajaran Biologi, 2(1), 5-9. https://doi.org/10.33369/diklabio.2.1.5-9.

Basri, A. M., Rohana, R., \& Pagarra, H. (2018). Penerapan Model Pembelajaran Discovery Learning untuk Meningkatkan Hasil Belajar Siswa pada Mata Pelajaran IPA Kelas V SDN 124 Batuasang Kecamatan Herlang Kabupaten Bulukumba. Publikasi Pendidikan, 8(3), 160. https://doi.org/10.26858/publikan.v8i3.5995.

Dharin, A., Aziz, K. D., \& Waseso, P. H. (2020). Pengembangan Pembelajaran Ilmu Pengetahuan Sosial Sekolah Dasar Berwawasan sSsial-Budaya. Portal Ejournal IAIN Purwokerto, 25(1), 1-14. http://ejournal.iainpurwokerto.ac.id/index.php/insania/article/view/3919.

Giri Radyana, Murda, I. N., \& Putu Ari Dharmayanti. (2017). Pengaruh Model Pembelajaran TAI Berbantuan Media Powerpoint terhadap Hasil Belajar Bahasa Indonesia Siswa kelas v. MIMBAR PGSD Undiksha, 5(2), 1-10. http://dx.doi.org/10.23887/jjpgsd.v5i2.10737.

Jayadiningrat, Gautama Made, Kadek Agus Apriawan Putra, P. S. E. A. P. (2019). Penerapan Model Discovery Learning untuk Meningkatkan Aktivitas dan Hasil Belajar Siswa. Diklabio: Jurnal Pendidikan dan Pembelajaran Biologi, 3(2), 83-89. https://doi.org/10.33369/diklabio.2.1.15-20.

Lidiana, H., Gunawan, G., \& Taufik, M. (2018). Pengaruh Model Discovery Learning Berbantuan Media PhET terhadap Hasil Belajar Fisika Peserta Didik Kelas XI SMAN 1 Kediri Tahun Ajaran 2017/2018. Jurnal Pendidikan Fisika Dan Teknologi, 4(1), 33. https://doi.org/10.29303/jpft.v4i1.519.

Lieung, K. W. (2019). Pengaruh Model Discovery Learning terhadap Keterampilan Berpikir Kritis Siswa Sekolah Dasar. Musamus Journal of Primary Education, 1(2), 073-082. https://doi.org/10.35724/musjpe.v1i2.1465.

Marhayani, D. A., \& Wulandari, F. (2020). Efektivitas Model Pembelajaran Kooperatif Tipe Make-A Match dalam Meningkatkan Kompetensi Sikap Siswa dan Kompetensi Pengetahuan Siswa pada Pelajaran IPS. Jurnal Ilmiah Sekolah Dasar, 4(1), 80. https: //doi.org/10.23887/jisd.v4i1.24047.

Muhammad, F., \& Hupiah, H. (2019). Penerapan Metode Discovery Learning untuk Meningkatkan Aktivitas Belajar dan Hasil Belajar Siswa Kelas XI IPS 1 MA Muallimin NW Pancor 2018/2019. JPEK (Jurnal Pendidikan Ekonomi Dan Kewirausahaan), 2(2), 107. https://doi.org/10.29408/jpek.v2i2.1065.

Nilayuniarti, N. P., Kt, D. B., \& Semara, N. (2020). Meningkatkan Kompetensi Pengetahuan IPS Melalui Model Pembelajaran Discovery Learning Berbasis Tri Hita Karana. 8(3), 445-456. http://dx.doi.org/10.23887/jjpgsd.v8i3.26043.

Ningtyas, E., \& Wuryani, E. (2017). Penerapan Model Pembelajaran Kooperatif (Cooperative Learning) Tipe Make-A Match Berbantuan Media Komik Interaktif untuk Meningkatkan Aktivitas Belajar dan Hasil Belajar IPS. Jurnal Pendidikan Surya Edukasi, 3(1), 66-74. http://ejournal.umpwr.ac.id/index.php/surya/article/view/3857/3619.

Pane, N. A., Nyeneng, I. D. P., \& Distrik, I. Wayan. (2020). The Effect Of Predict Observe Explain Learning Model Against Science Process Skills of High School Students. Jurnal Pendidikan Matematika dan 
IPA, 11(1), 112-119. http://dx.doi.org/10.26418/jpmipa.v11i1.32892.

Patandung, Y. (2017). Pengaruh Model Discovery Learning terhadap Peningkatan Motivasi Belajar IPA Siswa. Journal of Educational Science and Technology (EST), 3(1), 9. https: //doi.org/10.26858/est.v3i1.3508.

Rahmayani, A. (2019). Pengaruh Model Pembelajaran Discovery Learning dengan Menggunakan Media Video terhadap Hasil Belajar Siswa. Jurnal Pendidikan ( Teori Dan Praktik), 4(1), 59-62. https: //doi.org/10.47668/pkwu.v7i1.20.

Ratnadewi, A. (2018). Penerapan Discovery Learning Berbantuan Media Visual Untuk Meningkatkan Hasil Belajar IPS Siswa Kelas V. Jurnal Ilmiah Pendidikan Profesi Guru, 1(1), 20-28. https://doi.org/10.23887/jippg.v1i1.14210.

Rifky, H. \&. (2017). Pengembangan Media Pembelajaran Berbasis Komik pada Mata Pelajaran Ilmu Pengetahuan Sosial Kelas IV MI Nurul Hidayah Roworejo Negerikaton Pesawaran. Jurnal Pendidikan Dan Pembelajaran Dasar, 4(1), 34-46. https://doi.org/10.24042/terampil.v4i1.1804.

Salmi, S. (2019). Penerapan Model Pembelajaran Discovery Learning dalam Meningkatkan Hasil Belajar Ekonomi Peserta Didik Kelas XII IPS. 2 SMA Negeri 13 Palembang. Jurnal PROFIT Kajian Pendidikan Ekonomi Dan Ilmu Ekonomi, 6(1), 1-16. https://doi.org/10.36706/jp.v6i1.7865.

Sumitro, A. H., Setyosari, P., \& Sumarmi. (2017). Penerapan Model Problem Based Learning Meningkatkan Motivasi dan Hasil Belajar IPS. Jurnal Pendidikan:Teori, Penelitian, Dan Pengembangan, 2(9), 1188-1195. http://dx.doi.org/10.17977/jptpp.v2i9.9936.

Supanti. (2019). Penerapan Model Discovery Learning dalam Pembelajaran IPS untuk Meningkatkan Kemampuan Berpikir Kritis Siswa Kelas IXg SMP Negeri 1 Surakarta Tahun 2017/2018. Historika, 22(1), 59-70. https://doi.org/10.20961/historika.v22i1.29184.

Suprapti, E. (2016). Pengembangan Perangkat Pembelajaran Matematika Model Kooperatif Tipe STAD dengan Media Powerpoint Ispring pada Materi Jajargenjang, Layang-Layang dan Trapesium di Kelas VII SMP. MUST: Journal of Mathematics Education, Science and Technology, 1(1), 57. https: //doi.org/10.30651/must.v1i1.98.

Suryadewi, N. K. A., Wiyasa, I. K. N., \& Sujana, I. W. (2020). Kontribusi Sikap Mandiri dan Hubungan Sosial terhadap Kompetensi Pengetahuan IPS. MIMBAR PGSD Undiksha, 8(1), 29-39. http://dx.doi.org/10.23887/jjpgsd.v8i1.24576.

Wardani, I. A. K. dan K. W. (2020). Penelitian Tindakan Kelas. In Penelitian Tindakan Kelas. Universitas Terbuka. 